Journal of Experimental Zoology, Vol. 287, No. 1, 2000, pp. 96-105.

ISSN: (Print: 0022-104X) (Electronic: 1097-010X)

DOI: 10.1002/1097-010X(20000615)287:1<96::AID-JEZ13>3.0.CO;2-N

http://www3.interscience.wiley.com/journal/117928901/grouphome/home.html

(C) John Wiley \& Sons. All rights reserved.

This is a preprint of an article published in Journal of Experimental Zoology, Vol. 287, No. 1, 2000, pp. 96-105.

\title{
Induction of Gynogenesis in Muskellunge With Irradiated Sperm of Yellow Perch Proves Diploid Muskellunge Male Homogamety
}

\author{
KONRAD DABROWSKI, ${ }^{1}$ JACQUES RINCHARD, ${ }^{1}$ FENG LIN, ${ }^{1}$ MARY-ANN GARCIA- \\ ABIADO ${ }^{1}$ AND DANA SCHMIDT ${ }^{2}$ \\ ${ }^{1}$ School of Natural Resources, The Ohio State University, Columbus, Ohio, ${ }^{2}$ Division of Wildlife, Ohio Department \\ of Natural Resources, Kincaid State Fish Hatchery
}

\begin{abstract}
Diploid gynogenesis was induced in muskellunge Esox masquinongy using UV-irradiated muskellunge sperm as the first step in producing monosex females. In this approach, we have to rely on negative controls as an indirect reference for sperm genetic material destruction. In the first experiment, equal proportions of gynogenetic females and males were produced. Negative controls, UV-irradiated sperm without heat shock, yielded some normal hatching larvae, described as spontaneous diploids. In the second experiment, muskellunge eggs were activated using sperm from yellow perch. Because hybrids between these species are not viable, we produced unambiguous gynogens. When UV-irradiated yellow perch sperm was used to inseminate muskellunge eggs, haploids resulted $\left(22.5 \% \pm 2.8 \%\right.$ survival to the eyed stage). To produce diploid gynogens, a heat shock of $31^{\circ} \mathrm{C}$ was applied to inseminated eggs $20 \mathrm{~min}$ after activation for a duration of $6 \mathrm{~min}$. This process yielded several hundreds of gynogens for rearing. Several treatments of masculinizing hormone, $17 \alpha$-methyltestosterone (MT), were carried out. Fish were dissected and gonads examined histologically for sex determination. Gynogens produced using yellow-perch sperm confirmed the presence of males in the control group, whereas the MT bath treatment $(400 \mu \mathrm{g} / \mathrm{liter})$ resulted in the production of fish with ovotestis. These results provide evidence for male homogamety in muskellunge and imply that a change of strategy is needed to produce monosex populations.
\end{abstract}

Gynogenesis in fish has been studied in the past few decades for its potential value in experimental genetics and aquaculture (see reviews by Thorgaard, '83; Ihssen et al., '90). Gynogenesis can be achieved by retention of the second polar body or suppression of the first mitotic division of eggs inseminated with irradiated spermatozoa. When using UV-irradiated sperm of the same species, we have to rely on the negative controls as an indirect reference for sperm DNA destruction. However, this method cannot distinguish between incomplete UV irradiation of sperm and the spontaneous diploidization of gynogens. In both cases, diploids may be present in the haploid controls. In order to improve the technique of gynogenesis, sperm of different species is used to trigger the first division. The inactivated, heterologous sperm has been used successfully to produce gynogens of rainbow trout (Oncorhynchus mykiss; Chourrout, '86), tilapia (Oreochromis mossambicus; Varadaraj, '90), red sea bream (Pagrus major; Sugama et al., '90), fighting fish (Betta splendens; Kavumpurath and Pandian, '94), pink salmon (Oncorhynchus gorbuscha; Smoker et al., '95), tench (Tinca tinca; Linhart et al., '95a), paddlefish (Polyodon spathula; Mims et al., '97), honmoroko (Gnathopogon caerulescens; Fujioka, '98), white bass (Morone chrysops; Gomelsky et al., '98), and bitterling (Rhodeus ocellatus ocellatus; Kawamura, '98).

There have been reports that northern pike (Esox lucius) eggs inseminated with irradiated rainbow trout sperm developed to the gastrula stage with a survival rate of $47 \%$ (Chourrout, ' 82 ). Luczynski and colleagues ('98) suggested that northern pike have homogametic females, and these authors produced exclusively female gynogens in this species. Northern pike is a closely 
related species to muskellunge, therefore we anticipated the same inheritance system for gender in the latter.

The objectives of the present study therefore were to induce gynogenesis in the muskellunge Esox masquinongy, and to investigate the conditions for using heterologous sperm and analyze the proportion of males and females in the progeny. Furthermore, in anticipation of all-female progeny in experiments where heterologous sperm was used, we compared treatments with masculinizing hormone (17 $\alpha$-methyltestosterone) and response in blood steroid in order to provide additional information on sex differentiation in muskellunge.

\section{MATERIALS AND METHODS}

Muskellunge were captured by trap nets from Clear Fork Reservoir, Ohio, in 1996 and 1997. The fish were kept in a floating pen for 1-2 hr before being stripped of gametes, without anesthesia. The gametes were collected and kept at $10-12^{\circ} \mathrm{C}$ (eggs) or $0^{\circ} \mathrm{C}$ (sperm) during transport and storage to our laboratory at The Ohio State University, in Columbus. Sperm motility was checked before experimentation, and only semen with $>90 \%$ motility was used for irradiation and fertilization. For each experiment, sperm was pooled from three to five males and eggs from one to five females. In each experiment, eggs were fertilized with fresh sperm to serve as a control for gamete quality.

Yellow perch (Perca flavescens) were obtained from the Piketon Research and Extension Center (Piketon, $\mathrm{OH}$ ) from a semidomesticated stock kept in tanks and fed commercial salmonid feeds. Males were unanesthetized during semen collection, and sperm was stored on ice (at $0^{\circ} \mathrm{C}$ ) before irradiation or fertilization experiments.

In 1996, small-scale experiments using gynogens produced with UV-irradiated muskellunge and yellow-perch sperm were carried out, followed up with the mass production of gynogens with UV-irradiated muskellunge sperm (1996) and UV-irradiated yellow-perch sperm (1997).

\section{Embryos handling and hatching}

Previous research revealed that the storage of muskellunge eggs at $10-13^{\circ} \mathrm{C}$ for up to 8 hr secures good fertility (Lin and Dabrowski, '96). For small-scale experiments and massgynogen production, eggs were kept in sealed plastic bags under oxygen at $10-12^{\circ} \mathrm{C}$ for up to 5 hr. After fertilization or activation with UV-irradiated sperm, replicated samples (about 600 eggs unless otherwise stated) were incubated separately in PVC incubation baskets placed in California-type hatching trays (Flex-a-lite Consolidated, Tacoma, WA) with an exchange rate of 2-3 hr. Water temperature was $12-14^{\circ} \mathrm{C}$ during incubation, and from day 2 formalin was used daily at $50 \mathrm{ppm}$ concentration. Survival of embryos was monitored at closing of the blastopore (3 days) and eyed stage (7-9 days). The hatching rate and appearance of the embryos were used as a criteria to estimate haploidy/diploidy (Lin and Dabrowski, '96, '98).

\section{UV irradiation for sperm inactivation}

Sperm of muskellunge or yellow perch was diluted (1:4 and 1:9, respectively) with an immobilizing solution of $0.75 \% \mathrm{NaCl}$ and $0.6 \% \mathrm{KCl}$ (Varadaraj, '90). A portion of diluted sperm was placed on ice to serve as a control for the effect of dilution and storage on sperm fertility. The diluted semen was poured into a watch glass and UV-irradiated with a short wave (254 nm) of mineral light lamp (Model UVG-11 1 , UVP, Inc., San Gabriel, CA), at $520 \mu \mathrm{W} / \mathrm{cm}^{2}$. The sperm suspension was kept on ice during the irradiation (4 min). The intensity of UV irradiation 
was measured using an UVX radiometer (UVP, Inc.), with a sensor placed at the same level as the sperm suspension.

\section{Heat shock to inhibit the second meiosis}

Egg batches (600 each) were fertilized with control sperm prediluted in immobilizing solution or with irradiated spermatozoa, as described above. Approximately $0.1 \mathrm{ml}$ of the original sperm was used per batch of eggs. In mass gynogenesis, the proportion of sperm per egg was maintained $\left(1 \cdot 10^{6} / \mathrm{egg}\right)$, but the volume of diluted sperm irradiated at once did not exceed 2 $\mathrm{ml}$. Consequently, the eggs were then divided into several batches of 300-500 ml for separate heat-shock treatments and then combined.

Fluctuation of the water temperature was controlled within $0.1^{\circ} \mathrm{C}$, and water was circulated to ensure a homogenous temperature in each bath (volume 70 liters). Water during fertilization was $13.5^{\circ} \mathrm{C}$. In 1996 experiments, eggs were shocked at $31^{\circ} \mathrm{C}$ for a duration of 6 min, starting 13 or 20 min after activation (insemination), whereas in 1997 heat shock was applied only 20 min after activation. One batch of eggs activated with UV-irradiated sperm was not heat shocked and served as a negative haploid control. Another batch was used as a control, in which muskellunge eggs were inseminated with fresh yellow-perch sperm. Eggs were incubated in PVC baskets (1996 experiment) or McDonald jars (mass production, 1-2 liters of eggs, 1997) in the dark.

\section{Production of gynogens and sex reversal}

We performed two trials with large numbers of muskellunge eggs using the above methods. In 1996, about 2 liters of eggs were used and approximately 3,000 viable larvae were obtained. Fish were transferred to the Kincaid State Fish Hatchery in Latham, Ohio, and raised in concrete troughs. They were fed initially with newly hatched Artemia salina nauplii. After two weeks, the fish were divided into two groups: one transferred to dry pelleted feed, and the second offered newly hatched fathead minnows (Pimephales promelas). The fish fed dry pellets were supplied continuously (by belt feeders) with a commercial diet (Zeigler Bros Inc., Gardners, PA). At a total length of about $8 \mathrm{~cm}, 200$ fish fed live minnows and 46 fish fed a dry diet were transferred to the Columbus aquaculture facility and exposed to a $17 \alpha$-methyltestosterone (MT) treatment (Sigma Chemical Co., St. Louis, MO). The muskellunge on live food received minnows that were fortified with $500 \mathrm{mg} \mathrm{MT} / \mathrm{kg}$ salmon starter no. 1 for 3 days prior to being offered to muskellunge. The muskellunge on the dry diet were fed with salmon pellets sprayed with absolute ethyl-alcohol-dissolved MT to obtain a concentration of $10 \mathrm{mg} \mathrm{MT} / \mathrm{kg}$ diet. Following 2 or 3 months of treatment (live and dry feed, respectively) in October and November, the fish were sampled for histological sex determination. On October 7, 15 gynogens (without hormonal treatment) were also collected from the Kincaid State Fish Hatchery to serve as a control for the MT-treatment experiment.

In 1997, 500 gynogens (at hatching) were produced by activating muskellunge eggs, collected from five females, with UV-irradiated yellow-perch sperm and subjecting them to heat shock (see above for conditions). Gynogens were also produced with UV-irradiated muskellunge sperm, but raising was discontinued after subsamples were evaluated for eyed-stage and hatching survival. Gynogens produced with yellow-perch sperm are unambiguous gynogenetic females (assuming female homogamety in muskellunge) because hybrids between yellow perch and muskellunge are not viable.

The fish were fed live Artemia salina nauplii and then transferred to the Kincaid State 
Fish Hatchery for rearing. From June 9 through August 12, 374 3-week-old true muskellunge gynogens were maintained in a $6 \mathrm{~m}^{2}$ raceway and fed fathead minnows larvae and juveniles. On August 12, 100 fish (mean weight $8.5 \pm 3.1 \mathrm{~g}$, and mean length $130 \pm 17 \mathrm{~mm}$ ) were transferred to Columbus. The remaining fish (untreated control) were released to an earthen pond with fathead minnows for grow out.

The fish in Columbus were randomly assigned into two tanks (44 fish in a 400-liter tank) and fed live minnows ad libitum. Twelve fish were sacrified for the histological determination of sex ratio. The fish in the control group (tank) were immersed for $2 \mathrm{hr}$ in 15 liters of water containing $6 \mathrm{ml}$ ethyl alcohol once per week during 4 subsequent weeks. The MT-treated group was immersed for $2 \mathrm{hr}$ in 15 liter of water containing $400 \mathrm{~m} \mathrm{~g}$ MT/liter. MT was dissolved in 6 $\mathrm{ml}$ ethyl alcohol prior to the bath treatment. On September 1, the fish were anesthetized with a solution of MS-222, $50 \mathrm{mg} /$ liter (Argent Chemical Lab, Redmond, WA), weighed ( $\pm 0.1 \mathrm{~g}$ ), and measured $( \pm 1.0 \mathrm{~mm})$. The fish were then fin-clipped (pelvic fin) to distinguish three groups and stocked into the same pond with untreated controls at the Kincaid State Fish Hatchery. Fish were caught on March 2, 1998, measured for length, weighed, and their blood was sampled. Then they were sacrificed for histological gonad examination.

\section{Blood samples and plasma sex steroids}

On March 2, 1998, blood was sampled from gynogenetic muskellunge produced in 1997 and raised in a pond at the Kincaid State Fish Hatchery. Blood was obtained from the caudal vessel using a heparinized needle and syringe. The samples were kept on crushed ice until centrifugation at $1,500 \mathrm{~g}$ for $10 \mathrm{~min}$, after which plasma was removed, frozen, and stored at $20^{\circ} \mathrm{C}$ until radioimmunoassay (RIA). Plasma levels of testosterone (T) and estradiol-17ß (E2) were determined according to the methods similar to those of Ottobre and colleagues ('89). In both cases, the steroids were previously extracted with ethyl ether. Standard and radio-labelled $\mathrm{T}$ and E2 were obtained from ICN Pharmaceutical (Costa Mesa, CA) and NEN Life Science Products (Boston, MA), respectively. The T antiserum was provided by the Institute of Animal Physiology (University of Agriculture and Technology, Olsztyn, Poland), and the E2 antiserum by Dr. R. L. Butcher, of West Virginia University. The characteristics of these antisera have been previously reported (Butcher et al., '74; Dabrowski et al., '95). Both assays were validated for use with muskellunge blood plasma (Table 1).

\section{Examination of sex of gynogens}

Fish were dissected to open the body cavity and fixed in Bouin's solution for sex determination. After a week in fixative, fish smaller than $10 \mathrm{~cm}$ total length had bone and most of the muscle tissue removed, and samples were transferred to $70 \%$ ethyl alcohol. Each fish was cut into three pieces representing the anterior, middle, and posterior portion of the gonad. Larger fish were dissected and the gonads were fixed directly in Bouin's solution. The tissues were then dehydrated in a series of ethyl alcohol and xylene baths and embedded in paraffin. Thin sections $(5 \mu \mathrm{m})$ were cut and mounted on albumin-coated slides, which were then stained with Mayer's hematoxylin and eosin.

\section{Data analysis}

Statistical significance was assessed by a two-way analysis of variance (ANOVA) using the GLM procedure in SAS version 6.07 (SAS Institute, Inc., Cary, NC). The chi-square test was used for the analysis of alterations in sex ratios. Intersex fish were combined with females in the 
groups treated with $17 \alpha$-methyltestosterone so that only fish that were completely sex-reversed were recognized in the chi-square test as having been affected by the treatment. Homogeneity of variance was confirmed for all data, and all percentages were transformed using an arcsin transformation prior to analysis (Dagnelie, '75).

\section{RESULTS}

Gynogen production with homologous and heterologous sperm

In the 1996 experiments, embryo survival to the eyed stage of the control group was

TABLE 1. Radioimmunoassay characteristics of testosterone (T) and estradiol-17ß (E2) in muskellunge

\begin{tabular}{|c|c|c|}
\hline Characteristics & $\mathrm{T}$ & $\mathrm{E} 2$ \\
\hline $\begin{array}{l}\text { Within-assay coefficient of } \\
\text { variation }(\%)(\mathrm{n}=6)\end{array}$ & 0.54 & 1.00 \\
\hline $\begin{array}{c}\text { Between-assay coefficient } \\
\text { of variation }(\%)(\mathrm{n}=3)\end{array}$ & 2.04 & 1.27 \\
\hline Accuracy (coefficient of regression & 0.986 & 0.998 \\
\hline Sensitivity $(\mathrm{pg} / \mathrm{ml})$ & 1 & 1 \\
\hline Recovery of extraction (\%) & 97 & 94 \\
\hline Parallelism & \multicolumn{2}{|c|}{$\begin{array}{l}\text { Serial dilutions of plasma } \\
\text { samples showed parallelism } \\
\text { with the standard curve } \\
\text { between } 25 \text { and } 100 \mu l .\end{array}$} \\
\hline
\end{tabular}

$71.7 \% \pm 1.6 \%$ ( $\mathrm{n}=3$ females). The relative survival rate to the eyed stage for gynogenetic muskellunge was $75.5-79.0 \%$ for the group with UV-treated muskellunge sperm. No significant effect of heat-shock timing after egg activation (13 or $20 \mathrm{~min}$ ) was noticed (Fig. 1A). Eggs inseminated with UV-irradiated muskellunge sperm, but not heat shocked, produced $0.66 \% \pm$ $0.54 \%$ of diploid gynogens (based on morphological description; see Lin and Dabrowski, '96) (Fig. 1B).

Eggs of muskellunge fertilized with normal yellow-perch sperm produced no viable 


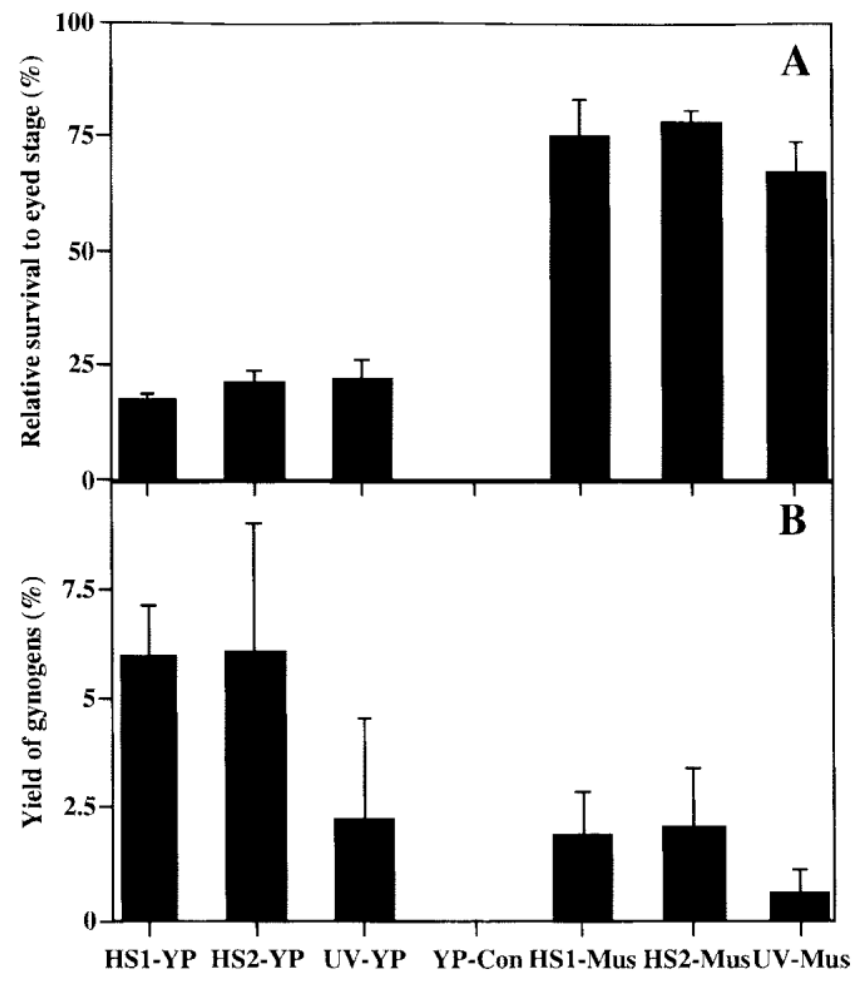

Fig. 1. Percentage of survival (mean \pm S.D.) to the eyed stage (A) and yield (B) of gynogenetic muskellunge subjected to various treatments in 1996. HS1-YP: muskellunge eggs fertilized with UV-irradiated yellow-perch sperm and exposed to heat shock $\left(31^{\circ} \mathrm{C}\right.$ for $\left.6 \mathrm{~min}\right) 13 \mathrm{~min}$ postfertilization. HS2-YP: muskellunge eggs fertilized with UV-irradiated yellow-perch sperm and exposed to heat shock $\left(31^{\circ} \mathrm{C}\right.$ for $\left.6 \mathrm{~min}\right) 20 \mathrm{~min}$ postfertilization. UV-YP: muskellunge eggs fertilized with UV-irradiated yellow-perch sperm. YP-CON: muskellunge eggs fertilized with yellow-perch sperm. HS1-Mus: muskellunge eggs fertilized with UV-irradiated muskellunge sperm and exposed to heat shock $\left(31^{\circ} \mathrm{C}\right.$ for $\left.6 \mathrm{~min}\right)$ 13 min post-fertilization. HS2-Mus: muskellunge eggs fertilized with UVirradiated muskellunge sperm and exposed to heat shock $\left(31^{\circ} \mathrm{C}\right.$ for $\left.6 \mathrm{~min}\right) 20$ min postfertilization. UV-Mus: muskellunge eggs fertilized with UV-irradiated muskellunge sperm to serve as negative control for UV irradiation.

embryos (Fig. 1A). Rainbow trout spermatozoa were also used, both untreated and UVirradiated, and no gastrulation was observed (data not shown). Diploid gynogens were obtained from eggs activated by UV-irradiated yellow-perch sperm when subjected to a heat shock (Fig. 1B). We also noticed some diploids (normal morphology) in the group not exposed to heat shock (group UV-YP, Fig. 1B). These fish were spontaneous gynogenetics (restored diploidization without intentional treatment). The ploidy of the muskellunge embryos was evaluated based on external normal features and confirmed using a flow cytometry method (see Lin and Dabrowski, '96, '98, data not shown).

In the 1997 experiment on the mass production of gynogens, the control group had a $89.3 \% \pm 4.1 \%$ survival to the eyed stage (Fig. 2 ). The hatching rate for gynogenetic muskellunge was $5.38 \% \pm 1.52 \%$ for the group with muskellunge sperm, and $1.84 \% \pm 0.01 \%$ for the group of yellow-perch sperm. No spontaneous diploidization was observed in this experiment in the group 
not subjected to heat shock. All embryos in the negative control group hatched as abnormal larvae with haploid syndrome.

Sex determination as the result of sex reversal by MT treatment

In gynogenetic fish produced in 1996 (mass production using UV-irradiated muskellunge

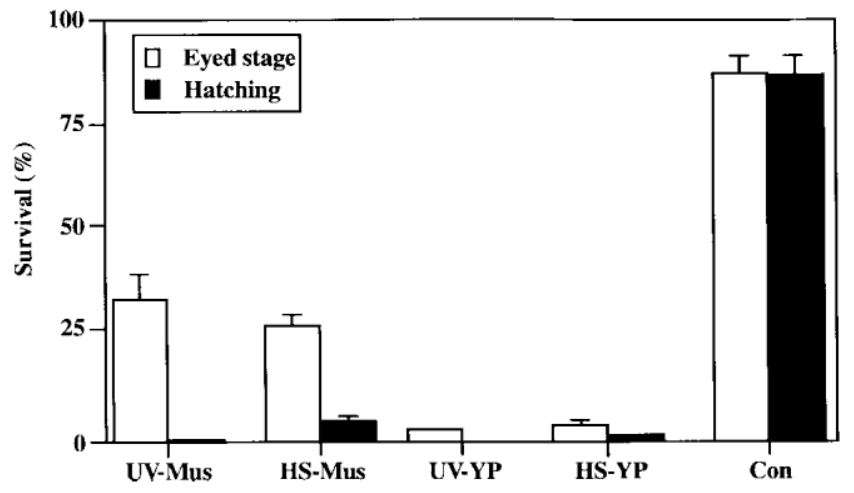

Fig. 2. Percentage of survival (mean \pm S.D.) to the eye stage and hatching of gynogenetic muskellunge subjected to various treatments in 1997. UV-Mus: muskellunge eggs fertilized with UV-irradiated muskellunge sperm to serve as negative control for UV irradiation. HS-Mus: muskellunge eggs fertilized with $\mathrm{UV}$-irradiated muskellunge sperm and exposed to heat shock $\left(31^{\circ} \mathrm{C}\right.$ for $\left.6 \mathrm{~min}\right)$ 20 min postfertilization. UV-YP: muskellunge eggs fertilized with UVirradiated yellow-perch sperm. HS-YP: muskellunge eggs fertilized with UVirradiated yellow-perch sperm and exposed to heat shock $\left(31^{\circ} \mathrm{C}\right.$ for $\left.6 \mathrm{~min}\right) 20$ min postfertilization. Con: muskellunge eggs fertilized with fresh muskellunge sperm as control for gamete quality.

sperm), we noticed testes in October to November in 6 out of 15 control group fish (without hormonal treatment) (Fig. 3). Among fish fed MT-treated fathead minnows, 3 were females $(\mathrm{n}=$ 5), whereas among fish fed with MT-containing pellets, 2 were females and 3 were males (Fig. 3). This indicated that neither treatment was able to accomplish complete sex reversal in muskellunge. Unfortunately, in the spring of 1997 the remaining fish in the hatchery pond were lost due to a flood.

In 1997, weights of gynogenetic muskellunge (mass production using UV-irradiated yellow-perch sperm) were measured immediately following four ethyl alcohol (control) or MT bath treatments, and no significant difference was found between groups, although overall growth was substantial (Fig. 4). Following the pond grow-out of three groups, significant differences $(P<0.01)$ were found in fish size between the treated control and the two other groups (untreated control and MT-treated) (Fig. 4), although the effect of selective mortality not directly related to treatment cannot be eliminated. Before MT treatment, histological examinations of gonad cross sections $(n=12)$ revealed that $42 \%$ of the fish had undifferentiated gonads and 58\% were females (Table 2). At the end of the experiment (March 2, 1998) the chisquare test revealed that the sex ratio obtained in each group did not significantly differ from the one observed before the MT treatment, assuming that all undifferentiated gonads become testes in fish of this size (Lin et al., '97) (Table 2). Moreover, intersex gonads (with the presence of 
testicular and ovarian tissues) were found in treated control and MT-treated groups. Those results indicated that MT bath treatments were not able to accomplish complete sex reversal in muskellunge.

\section{Plasma sex steroids}

There were no significant differences in plasma T levels between sexes (Fig. 5); however, individual $\mathrm{T}$ values varied widely, from nondetectable levels to $300 \mathrm{pg} / \mathrm{ml}$. Females presented the highest levels of T and E2 (124 and $107 \mathrm{pg} / \mathrm{ml}$, respectively). The levels of plasma E2 were significantly higher in females and intersex fish $(P<0.01)$ than in males (Fig. 5). The concentrations of $\mathrm{T}$ and $\mathrm{E} 2$ in intersex fish were similar (78 and $84 \mathrm{pg} / \mathrm{ml}$, respectively).

\section{DISCUSSION}

In the present study, gynogenetic muskellunge were produced using homologous 

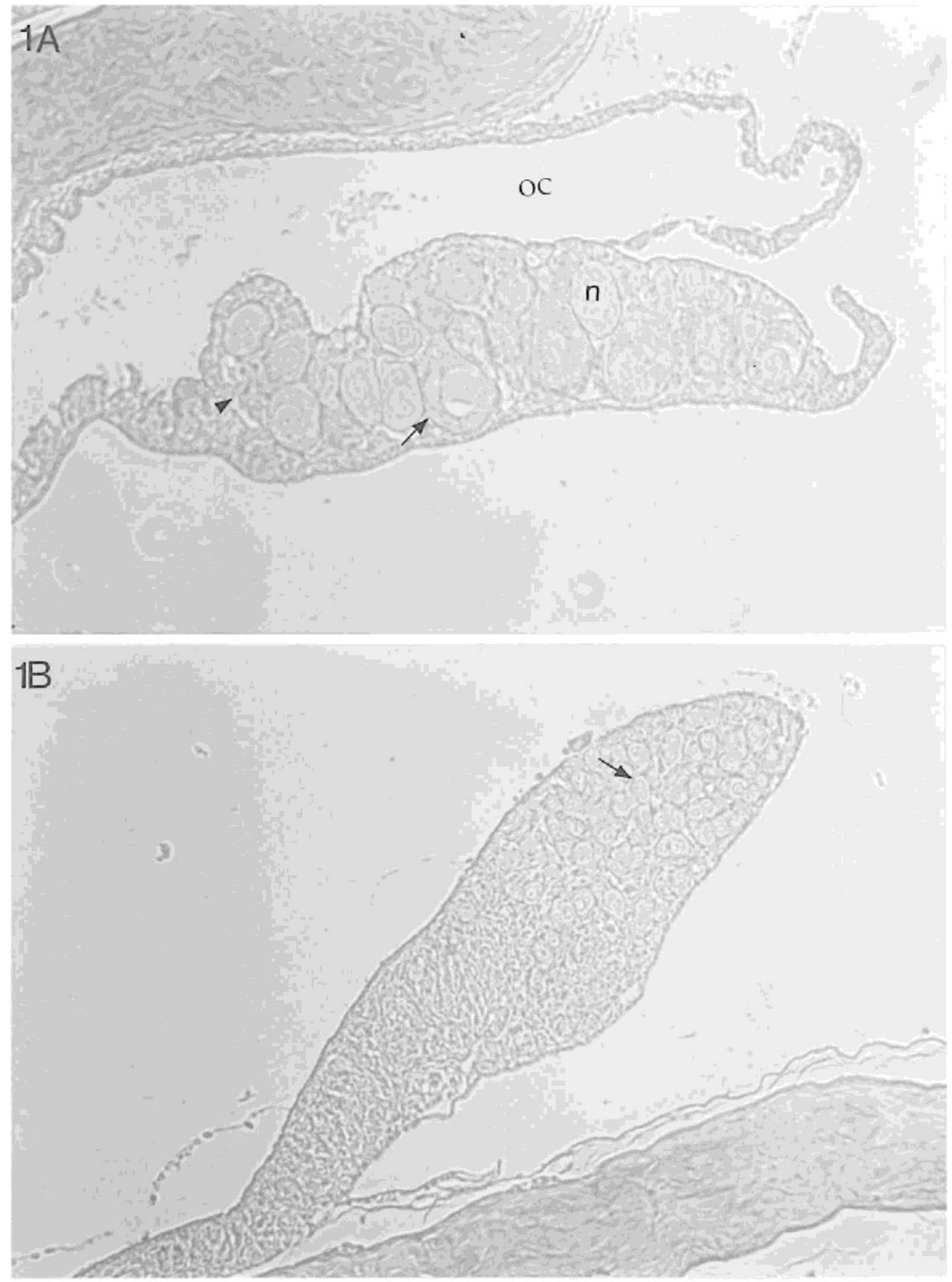

Fig. 3. Gonads of muskellunge from the control group. A: An ovary with ovarian cavity (oc), groups of early prophase oocytes (arrowheads), and large oocytes (arrow) with nucleus (n). Magnification $\times 420$. B: A testis with spermatogonia (arrow) concentrated at the tip of the gonad away from the coelom wall. Magnification $\times 420$. 


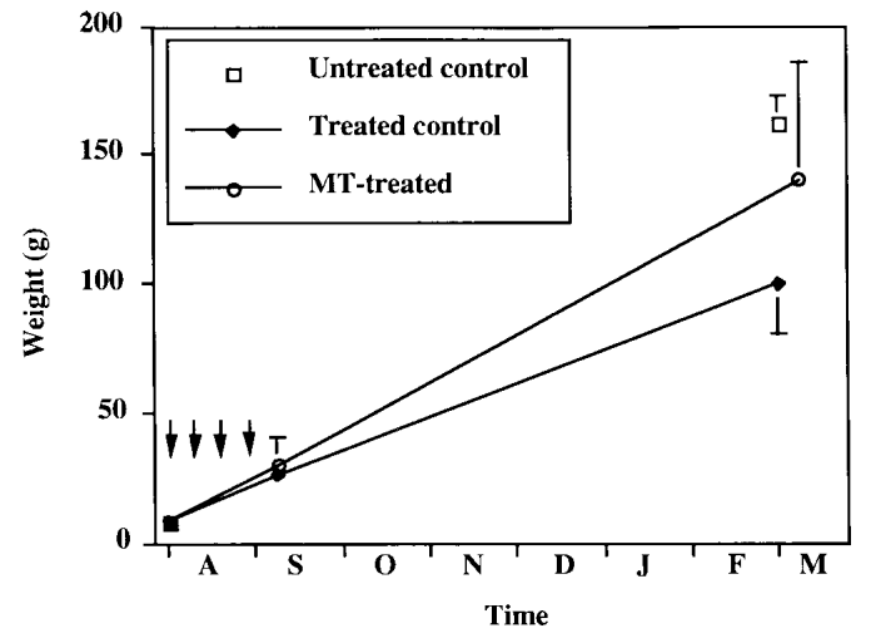

Fig. 4. Effects of immersion exposures with $17 \alpha$-methyl-testosterone (MT) on the weight of muskellunge. Data are presented as mean \pm SE. Error bars that are essentially equal or smaller than the data point symbols are not presented.

(muskellunge) and heterologous (yellow perch) UV-irradiated sperm. Lin and Dabrowski ('96) reported that the optimal condition for UV irradiation of muskellunge sperm ranged between 1,400 and $2,160 \mathrm{~J} / \mathrm{m}^{2}$ (4-6 min); however, the present results showed that the genetic material of the spermatozoa from both species, muskellunge and yellow perch, was already destroyed at $1,248 \mathrm{~J} / \mathrm{m}^{2}$, and the spermatozoa maintained their ability to activate egg (haploid) development. We also modified the conditions of the heat-shock treatment to improve the yield of gynogens. However, the increase of the heat-shock temperature $\left(31^{\circ} \mathrm{C}\right.$ in the present experiment vs. $30^{\circ} \mathrm{C}$ in Lin and Dabrowski, '96) and the decrease of its duration (6 min in the present experiment vs. 8 $10 \mathrm{~min}$ in Lin and Dabrowski, '96) did affect the yield of gynogens.

As reported in numerous species, gynogenesis was induced by using heterologous sperm

TABLE 2. Effect of immersion exposures of $17 \alpha$-methyltestosterone on gonadal development in muskellunge gynogens expressed as percentage of analyzed fish

\begin{tabular}{|c|c|c|c|c|}
\hline & & \multicolumn{3}{|c|}{$\begin{array}{l}- \\
\text { Final sampling }\end{array}$} \\
\hline & $\begin{array}{c}\text { Before } \\
\text { treatment }\end{array}$ & $\begin{array}{l}\text { Untreated } \\
\text { control }\end{array}$ & $\begin{array}{l}\text { Treated } \\
\text { control }\end{array}$ & $\begin{array}{c}\text { MT } \\
\text { treated }\end{array}$ \\
\hline Analyzed fish (n) & 12 & 12 & 12 & 18 \\
\hline Undifferentiated & 42 & 0 & 0 & 0 \\
\hline Female & 58 & 33 & 42 & 55 \\
\hline Male & 0 & 67 & 42 & 39 \\
\hline Intersex & 0 & 0 & 16 & 6 \\
\hline
\end{tabular}




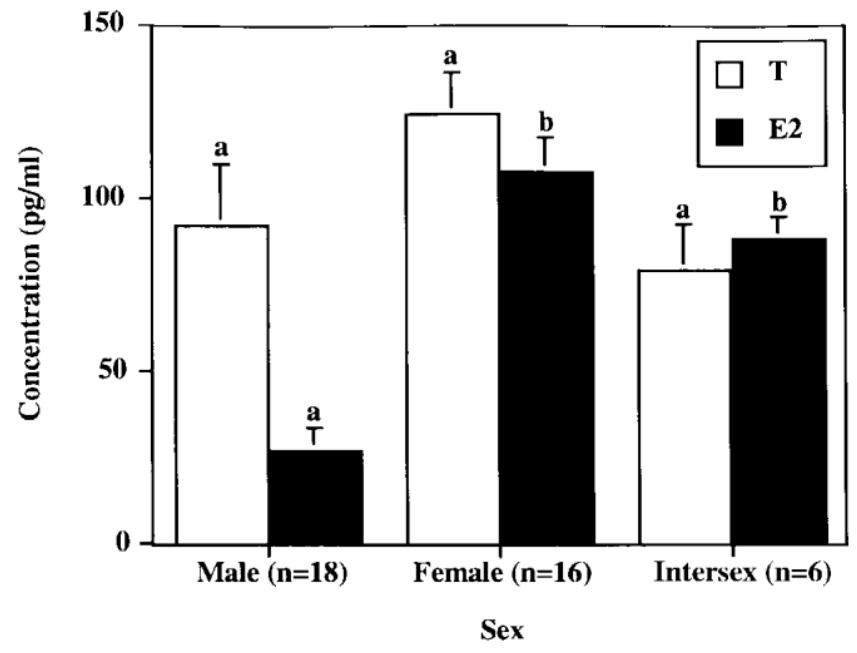

Fig. 5. Concentrations of plasma testosterone (T) and estradiol-17ß (E2) in male and female gynogenetic muskellunge (combination of control and MT-treated fish). Data are presented as mean $\pm \mathrm{SE}$. For each steroid, means with the same letter were not significantly different $(P>0.05)$. The numbers indicate the number of fish sampled.

from a related species. Normal yellow-perch sperm could initiate the development of muskellunge eggs; however, the hybrids did not survive beyond the gastrula stage, and no viable embryos were found when muskellunge eggs were fertilized with yellow-perch sperm. Esocid eggs appear particularly susceptible to parthenogenetic development (Kasansky, '34); however, embryonic development ceases at early gastrula stages. Therefore, all diploids produced in this way are unambiguous gynogens. Spontaneous diploidization of maternal chromosomes upon egg activation has been described in cyprinids (Cherfas et al., '95). The present finding is the first description of this phenomena in esocids. As this was found only in 1 year of study, it seems to be related to females.

Although the yields of gynogens produced using UV-irradiated yellow-perch sperm were low, they were similar to those reported using UV-irradiated muskellunge sperm. Chourrout ('87) and Ihssen and colleagues ('90) emphasized that the low rate of gynogens produced is a consequence of the critical conditions of the heat-shock treatment as well as possible inbreeding. In northern pike, Luczynski and colleagues ('97) reported that up to $35 \%$ gynogens can be produced when eggs are subjected to heat shock of $34^{\circ} \mathrm{C}$ for $3 \mathrm{~min}$ at $14 \mathrm{~min}$ after fertilization. In 1996, gynogenetic muskellunge were produced using UV-irradiated yellow-perch sperm and without the application of heat shock, the consequence of a spontaneous diploidization. These findings were similar to those reported for a cyprinid fish, tench (Linhart et al., '95a), in which the level of spontaneous diploidization was correlated to the duration of short-term storage of eggs (Linhart et al., '95b).

Based on the general rule of female homogamety, fish produced by gynogenesis should be only females. Therefore, the presence of males and females in equal proportion in the gynogenetic group produced in 1996 (using UV-irradiated muskellunge sperm) implies that some fish were either a result of fertilization by normal muskellunge sperm that were not completely inactivated by UV irradiation, or females are heterogametic and possess ZW chromosomes, as recently described in a cyprinid fish, the barbel Barbus barbus (Castelli, '96). 
This later hypothesis was reinforced by the results obtained in 1997 (the sex ratio of the gynogenetic group $=0.6: 0.4$; female:male). If the genetic material of yellow-perch sperm was not completely inactivated by UV-irradiation, the hybrids resulting from the muskellunge egg fertilization were not viable. Therefore, it appears that in the genus Esox, as reported in genus Oreochromis (Trombka and Avtalion, '93), both systems XY and WZ could coexist. Luczynski and colleagues ('97) reported that in northern pike all gynogenetic fingerlings were females and suggested that in this species the homogamety of females (XX) exists. To confirm evidence that the female muskellunge is heterogametic, we are currently conducting an experiment that includes mating gynogenetic females with normal males and gynogenetic males with normal females. The sex ratio of these pairs of offspring will validate the current assumption. If the progenies were to show a sex ratio close to $1: 1$, or $100 \%$ females, respectively, the hypothesis that the female is heterogametic (WZ) and the male if homogametic (ZZ) would be demonstrated.

Masculinization of muskellunge has been carried out by using MT. Three different methods were used: two different oral administrations (live and dry food) and an immersion treatment. Although MT treatment was applied throughout the period of gonadal differentiation (fish size between 119 and $151 \mathrm{~mm}$ and between 192 and $229 \mathrm{~mm}$ in female and male, respectively; Lin et al., '97), none of these methods were successful in producing complete masculinization. Among the different factors affecting the sex reversal suggested by Mirza and Shelton ('88), the dose and duration of the MT treatment seem to be predominant in the unsuccessful masculinization of muskellunge. For instance, it was reported that high concentrations of MT did not change the sex ratio in rainbow trout (Bieniarz et al., '91). Paradoxical feminization of muskellunge was also observed by Rinchard and colleagues ('99) when fish were fed with feed containing MT at a concentration of $15 \mathrm{mg} / \mathrm{kg}$ for 60 days. Therefore, further investigations are needed to elucidate the correct dosage of MT and the duration of its application necessary to ensure a complete masculinization in this species.

The growth of MT-treated fish appeared to be similar to that of the nontreated muskellunge and was continuously maintained in the pond at the Kincaid State Fish Hatchery. Thus, the significant difference in growth observed between the two treated groups (ethanol or MT) may be attributed to the MT treatment. The anabolic effects of MT on growth has been previously reported in several species, such as common carp (Lone and Matty, '80), rainbow trout (Ostrowski and Garling, '87), and cichlids (Kuwaye et al., '93; Green and TeichertCoddington, '94). For the first time, this androgen was shown to have an effect on the growth of muskellunge; however, the magnitude of the response to MT depends on many factors, including age, size, developmental stage, temperature, salinity, dietary factors, treatment duration, season, and method of application (Higgs et al., '82). Thus, muskellunge fed a diet containing MT at a dose of $15 \mathrm{mg} / \mathrm{kg}$ of food for 60 days did not significantly increase their growth in comparison to controls (Rinchard et al., '99). Although low levels of plasma sex steroids were found in male and female muskellunge, a significant difference in plasma E2 was observed between males and females. Therefore, it appears that the concentration of this estrogen can be used to discriminate the sex in this species; however, as similar E2 levels were found in intersex and female fish, histological analysis remained the only way to determine the sex of muskellunge.

\section{ACKNOWLEDGMENTS}

This work was funded by the Federal Aid in Sport Fish Restoration Program (F-69-P, Fish Management in Ohio), administered jointly by the U.S. Fish and Wildlife Service and the 
Ohio Division of Wildlife. We are indebted to the staff from the Kincaid State Fish Hatchery in Kincaid, Ohio, for their technical assistance. We thank Dr. Joseph Ottobre (Department of Animal Sciences, The Ohio State University) for access to his laboratory for endocrinological analysis, and Travis Hartman for help in the preparation of this manuscript. Salaries were partly provided by state and federal funds awarded to the Ohio Agriculture Research and Development Center in Wooster, Ohio.

\section{LITERATURE CITED}

Arai K, Matsubara K, Suzuki R. 1993. Production of polyploids and viable gynogens using spontaneously occurring tetraploid loach, Misgurnus anguillicaudatus. Aquaculture 117:227-235.

Bieniarz K, Goryczko K, Dobosz S, Grudniewski T. 1991. The effects of $17 \infty$-methyltestosterone on rainbow trout (Oncorhynchus mykiss). Pol Arch Hydrobiol 38:295-301.

Butcher RL, Collins WE, Fugo NW. 1974. Plasma concentration of LH, FSH, prolactin, progesterone and estradiol$17 ß$ throughout the 4-day estrous cycle of the rat. Endocrinology 94:1704-1708.

Castelli M. 1996. Study on sex determination in the common barbel (Barbus barbus L.) (Pisces, Cyprinidae) using gynogenesis. In: Beaumont AR, editor. Genetics and evolution of aquatic organisms. London: Chapman and Hall. p 509-519.

Cherfas N, Gomelsky B, Ben-Dom N, Hulata G. 1995. Evidence for the heritable nature of spontaneous diploidization in common carp, Cyprinus carpio L., eggs. Aquacult Res 26:89-292.

Chourrout D. 1982. Gynogenesis caused by ultraviolet irradiation of salmonid sperm. J Exp Zool 223:175-181.

Chourrout D. 1986. Use of grayling sperm (Thymallus thymallus) as a marker for the production of gynogenetic rainbow trout (Salmo gairdneri). Theor Appl Genet 72: 633-636.

Chourrout D. 1987. Genetics manipulations in fish: review of methods. In: Tiews K, editor. Selection, hybridization, and genetic engineering in aquaculture, vol. 2. Berlin: Heenemann. p 111-125.

Dabrowski K, Ciereszko RE, Blom JH, Ottobre JS. 1995. Relationship between vitamin C and plasma testosterone in female rainbow trout Oncorhynchus mykiss. Fish Physiol Biochem 14:409-414.

Dagnelie P. 1975. Théorie et méthodes statistiques: applications agronomiques. Volume 2: Les Méthodes de l'Inférence Statistique. Gembloux, Belgium: Les Presses Agronomiques de Gembloux.

Day R, Stevenson F. 1989. Evaluation of muskellunge in Clear Fork Reservoir. Final report of management evaluation conducted under Federal Aid Fish Restoration Project R-29-R-23 through R-28. Ohio Department of Natural Resources.

Dombeck MP, Menzel BW, Hinz PM. 1984. Muskellunge spawning habitat and reproductive success. Trans Am Fish Soc 113:205-216.

Dunham RA. 1990. Production and use of monosex or sterile fishes in aquaculture. Aquat Sci 2:1-17.

Fujioka Y. 1998. Survival, growth, and sex ratios of gynogenetic diploid honmoroko. J Fish Biol 52:430-442.

Gomelski B, Cherfas NB, Gissis A, Hulata G. 1998. Induced diploid gynogenesis in white bass. Prog Fish Cult 60:288-292.

Green BW, Teichert-Coddington DR. 1994. Growth of control and androgen-treated Nile tilapia, Oreochromis niloticus (L.), during treatment, nursery, and grow-out phases in tropical fish ponds. Aquacult Fish Manag 25:613-621.

Higgs DA, Fagerlund UHM, Eales JG, McBride JR. 1982. Application of thyroid and steroid hormones as anabolic agents in fish culture. Comp Biochem Physiol 73B:143-176.

Ihssen PE, McKay LR, McMillan I, Phillips RB. 1990. Ploidy manipulation and gynogenesis in fishes: cytogenetic and fisheries applications. Trans Am Fish Soc 119:698-717.

Kasansky WJ. 1934. Die parthenogenetische Entwicklung der Hechteier (Esox lucius L.). Zoo Anz Bd 86:161-163.

Kavumpurath S, Pandian TJ. 1994. Induction of heterozygous and homozygous diploid gynogenesis in Betta splendens (Regan) using hydrostatic pressure. Aquacult Fish Manag 25:133-142.

Kawamura K. 1998. Sex determination system of the rosy bitterling, Rhodeus ocellatus ocellatus. Environ Biol Fish 52:251-260.

Komen J, Duynhouwer J, Richter CJJ, Huisman EA. 1988. Gynogenesis in common carp (Cyprinus carpio L.). I. Effects of genetic manipulation of sexual products and incubation condition of eggs. Aquaculture 69:227239.

Kuwaye TT, Okimoto DK, Shimoda SK, Howerton RD, Lin HR, Pang PKT, Grau EG. 1993. Effect of 17œmethyltestosterone on the growth of the euryhaline tilapia, Oreochromis mossambicus, in freshwater and in 
seawater. Aquaculture 113:137-152.

Lin F, Dabrowski K. 1996. Effects of sperm irradiation and heat shock on induction of gynogenesis in muskellunge (Esox masquinongy). Can J Fish Aquat Sci 53:2067-2075.

Lin F, Dabrowski K. 1998. Androgenesis and homozygous gynogenesis in muskellunge (Esox masquinongy): evaluation using flow cytometry. Mol Reprod Dev 49:10-18.

Lin F, Dabrowski K, Timmermans LPM. 1997. Early gonadal development and sexual differentiation in muskellunge (Esox masquinongy). Can J Zool 75:1262-1269.

Linhart O, Kvasnicka P, Flajshans M, Kasal A, Rab P, Palecek J, Slechta V, Hamackova J, Prokes M. 1995a. Genetic studies with tench, Tinca tinca L.: induced meiotic gynogenesis and sex reversal. Aquaculture 132:239-251.

Linhart O, Flajshans M, Kvasnicka P. 1995b. Gynogenesis of tench (Tinca tinca L.) after short-time storage of eggs. Aquaculture 129:135.

Lone KP, Matty AJ. 1980. The effect of feeding methyltestosterone on the growth and body composition of common carp (Cyprinus carpio L.). Gen Comp Endocrinol 40: 409-424.

Luczynski MJ, Glogowski J, Kucharczyk D, Luczynski M, Demska-Zakes K. 1997. Gynogenesis in northern pike (Esox lucius L.) induced by heat shock: preliminary data. Pol Arch Hydrobiol 44:25-32.

Malison JA, Kayes TB, Held JA, Barry TP, Amundson CH. 1993. Manipulation of ploidy in yellow perch (Perca flavescens) by heat shock, hydrostalic pressure shock, and spermatozoa inactivation. Aquaculture 110:229242.

Mims SD, Shelton WL, Linhart O, Wang C. 1997. Induced meiotic gynogenesis of paddlefish Polyodon spathula. J World Aquacult Soc 28:334-343.

Mirza JA, Shelton WL. 1988. Induction of gynogenesis and sex reversal in silver carp. Aquaculture 68:1-14.

Ostrowski AC, Garling DL Jr. 1987. Effect of 17œ-methyltes-tosterone treatment and withdrawal on growth and dietary protein utilization of juvenile rainbow trout fed practical diets varying in protein level. $\mathrm{J}$ World Aquacult Soc 18: 71-77.

Ottobre JS, Houmard BS, Ottobre AC. 1989. Luteal production of steroids and prostaglandins during stimulated early pregnancy in the primate: differential regulation of steroid production by chorionic gonadotropin. Biol Reprod 41: 393-400.

Pongthana N, Penman DJ, Karnasuta J, McAndrew BJ. 1995. Induced gynogenesis in the silver barb (Puntius gonionotus Bleeker) and evidence of female homogamety. Aquaculture 135:267-276.

Rinchard J, Dabrowski K, Garcia-Abiado MA, Ottobre J. 1999. Uptake and depletion of plasma $17 \infty-$ methyltestosterone during induction of masculinization in muskellunge, Esox masquinongy: effect on plasma steroids and sex reversal. Steroids 64:518-525.

Scott WB, Crossman EJ. 1973. Freshwater fishes of Canada. Bull Fish Res Board Can, Ottawa, 184. 966 p.

Shelton WL. 1986. Broodstock development for monosex production of grass carp. Aquaculture 57:311-319.

Smoker WW, Crandell PA, Matsuoka M. 1995. Second polar body retention and gynogenesis induced by thermal shock in pink salmon, Oncorhynchus gorbuscha (Walbaum). Aqua-cult Res 26:213-219.

Sugama K, Taniguchi N, Seki S, Nabeshima H, Hasegawa Y. 1990. Gynogenetic diploid production in the red sea bream using UV-irradiated sperm of black sea bream and heat shock. Nippon Suisan Gakkaishi 56:14271433.

Thorgaard GH. 1983. Chromosome set manipulation and sex control in fish. In: Hoar WS, Randall FJ, Donaldson EM, editors. Fish physiology, vol. 9B. New York: Academic Press. p 405-434.

Trombka T, Avtalion R. 1993. Sex determination in tilapia: a review. Israel J Aquacult 45:26-37.

Varadaraj K. 1990. Production of diploid Oreochromis mossambicus gynogenesis using heterozygous sperm of Cyprinus carpio. Indian J Exp Biol 28:701-705. 